\title{
Study of Formic and Acetic Acids in the Air of Humid Savannah Case of Lamto (Cote d'Ivoire)
}

\author{
Pêlèmayo Raoul Touré1, Georges Kouame Kouadio, ${ }^{1,2}$, Urbain Kouakou Koffi², \\ Charles Romaric Beugré ${ }^{3}$ \\ ${ }^{1}$ Laboratory of Atmospheric Physics and Fluid Mechanics (LAPA-MF), Félix Houphouët-Boigny University, \\ Abidjan, Côte d'Ivoire \\ ${ }^{2}$ Physcal Science Laboratory of the Ecole Normale Supérieure of Abidjan (ENS), Abidjan, Côte d'ivoire \\ ${ }^{3}$ Laboratory of physical chemistry, Félix Houphouët-Boigny University, Abidjan, Côte d'Ivoire \\ Email: pelemayo@gmail.com
}

Received 22 January 2016; accepted 10 April 2016; published 13 April 2016

Copyright (C) 2016 by authors and Scientific Research Publishing Inc.

This work is licensed under the Creative Commons Attribution International License (CC BY).

http://creativecommons.org/licenses/by/4.0/

c) (i) Open Access

\begin{abstract}
From January 1995 to December 2004, 860 rainwater samples were collected in the humid savannah of Lamto. Using the Henry's law, we determined the content of formic and acetic acids in the air based on their concentrations in rainwater. The annual partial pressure of both formic and acetic acids over the decade is variable. It covers a range of 0.003 (1998) to $0.21 \mathrm{ppbv}(1996)$ and 0.27 (1999) to $0.47 \mathrm{ppbv}$ (1996) for formic and acetic acids respectively. Also, the partial pressure in the dry season is higher than that in the wet season. This difference is related to the enrichment of the organic acid content in the air by the various sources that produce these acids. One of the main sources of increment in organic acid is biomass burning. This biomass burning contributes between $\mathbf{2 1 \%}$ and $\mathbf{5 1 \%}$ to the formation of the two acids in the humid savannah of Lamto. Ultimately the average annual organic acidity varies from $40 \%$ to $60 \%$ over the ten years period.
\end{abstract}

\section{Keywords}

Formic Acid, Acetic Acid, Organic Acidity, Biomass Burning

\section{Introduction}

Numerous field investigations of organic acids in the boundary layer and through the free troposphere have been undertaken in situ and remotely during isolated, time limited local as well as regional studies for more than three

How to cite this paper: Touré, P.R., Kouadio, G.K., Koffi, U.K. and Beugré, C.R. (2016) Study of Formic and Acetic Acids in the Air of Humid Savannah Case of Lamto (Cote d'Ivoire). Atmospheric and Climate Sciences, 6, 254-266.

http://dx.doi.org/10.4236/acs.2016.62021 
decades. The results indicate that formic and acetic acids are ubiquitous components of the atmosphere [1]-[6]. They are significant contributors to rain acidity in remote environments $(16 \%-65 \%)$ and also regulate aqueous reactions with pH-dependence in cloud [7]-[10]. They remain an important interest for environmental researchers since they can be used as automobile pollution tracers. Formic and acetic acids can be primary pollutants from motor vehicles [11] and biomass combustion [12]. This observation led authors to suggest the use of ratio of Acetic to Formic acids as an index of pollution [6] [11]-[13]. Sources of these acids are not sufficiently understood [14]. The predominant source of formic acid (FA) and acetic acid (AA) is thought to be photochemical degradation of biogenic volatile organic compounds (VOCs), in particular isoprene and its oxidation products [15] [16]. Moreover, other sources include oxidation of anthropogenic and pyrogenic volatile organic compounds (VOCs) [9] [16] [17] and direct emissions from biomass and biofuel burning [18] [19] and terrestrial vegetation [6] [20] [21]. Ozonolysis of simple alkenes in the presence of water vapour has been identified as possible source of organic acids [22] [23]. In-cloud aqueous phase oxidation by HO radicals of acetaldehyde has been estimated to be too slow to significantly impact the formation of acetic acid over the Amazonian boundary layer [24] [25]. Possible sources, for formic acid, are ants and rocks [26] [27]. Among these sources, the contribution of savannah soils, ants, rocks, and in-cloud formation is very uncertain, but most probably minor [21].

Carboxylic acids measurement methods are numerous and various (e.g., Mist chamber technique [28]-[30], embedded measurement devices in balloons [31], in the free troposphere by aircraft measurements [32]-[34] etc.). All these measurement methods are more or less complex and require a lot of logistical and financial resources for their implementation. For this reason there are few earlier studies over Africa on these acids in the gaseous phase. However, numerous studies on the physicochemical precipitation have shown that carboxylic acids (mostly, formic and acetic acids) contribute between $30 \%$ and $70 \%$ to the total free acidity of rainwater [35]-[38]. This contribution increases from the arid savannah of Sahel to tropical forest over this continent [37]-[39]. Therefore, our study is a contribution to the understanding of the variation in levels of formic and acetic acids in the boundary layer of the humid savannah of Lamto. Thus, the main purpose of this study is to estimate and analyse the variations in levels of these two acids in the atmosphere from their concentration in rainwater. We have used Henry's law for the estimation. Subsequently, an analysis of the impact of biomass burning on this variability is also conducted.

\section{Materials and Methods}

\subsection{Experimental Site}

Lamto geophysical station is located in West Africa precisely in Côte d'Ivoire. Since 1994 it has became IDAF (IGAC/DEBITS/Africa: International Global Atmospheric Chemistry/Deposition of Biogeochemically Important Trace Species/AFrica) network experimental site, where it characterises the humid savannah ecosystem. This station is located between the Guinean savannah and tropical forest $\left(6^{\circ} 31^{\prime} \mathrm{N}\right.$ latitude and $5^{\circ} 02^{\prime} \mathrm{W}$ longitude), Figure 1. Previous studies [38] [40] have shown that 2 main air mass influence the chemical composition of rainfall in Lamto. Harmattan wind rich in $\mathrm{Ca}^{2+}$ contained in aeolian particles under gypsum $\left(\mathrm{CaSO}_{4}\right)$, calcite $\left(\mathrm{CaCO}_{3}\right)$ or dolomite $\left(\mathrm{CaMg}\left(\mathrm{CO}_{3}\right)\right)$. The $\mathrm{Cl}^{-}$are for those emanating from the maritime salts [38] [40]. Other anthropogenic sources of the main chemical components are from Coffee, Cocoa, pineapple, domestic cooking and biomass burning of the people living in the surrounding areas [38] [40]. The climate of the Lamto station is controlled by the Inter-Tropical Convergence Zone (ITCZ), boundary between the moist and hot air from ocean (Monsoon) and dry and hot air from the continent (Harmattan). Thus, Lamto has a bimodal seasonal rainfall characterised by 4 periods, 2 rainy seasons distinguished by a long dry season from December to February and rainfall recession in August, with an average of $1200 \mathrm{~mm} \cdot \mathrm{year}^{-1}$ [38] [40] [41]. The monthly mean temperature is about $27^{\circ} \mathrm{C}$ and less from one season to another. At Lamto, average monthly relative humidity in the area Lamto above $50 \%$. The values are between $65 \%$ and $83 \%$. The months of June and July have the highest relative humidity value about $82 \%$.

\subsection{Sources of Data}

For this study, we used two types of data. The meteorological data produced by Ivory Coast Meteorological Agency (SODEXAM). They have been used to determine the seasonal distribution of rainfall at Lamto during the period of study and to calculate the dryness index. Physicochemical data of rain waters have been supplied 


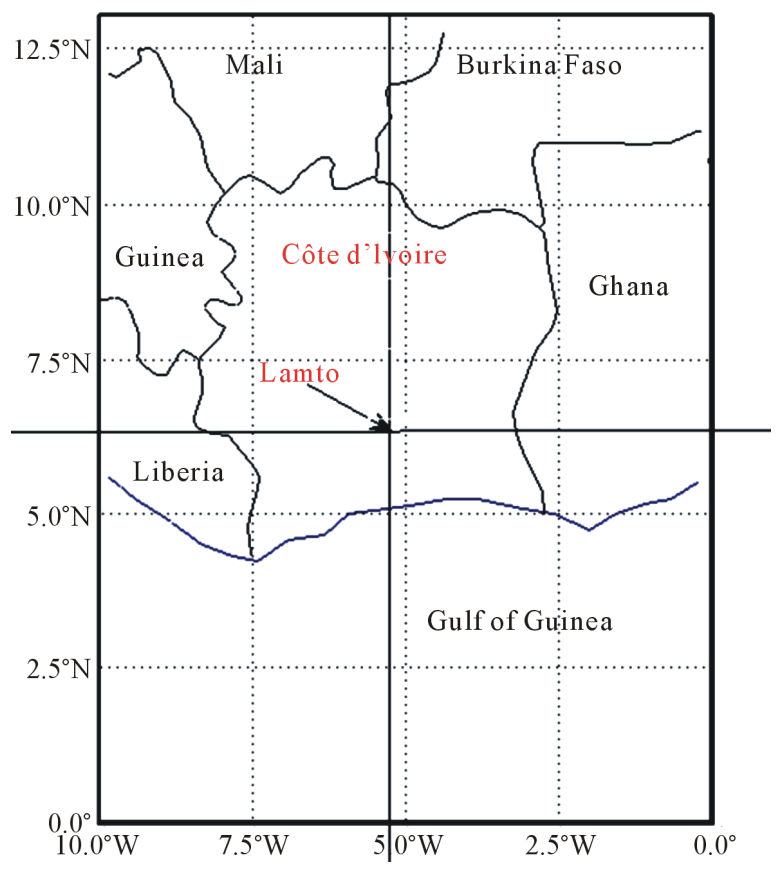

Figure 1. The Lamto station location.

by IDAF network and used to determine the partial pressures of formic and acetic acids.

\subsubsection{Seasonal Distribution of Rainfall in Lamto from 1994 to 2004}

The seasonal distribution of rainfall was defined based on Gaussen and Bagnouls [42] (Table 1) for each year. For a monthly rainfall ( $\mathrm{P}$ in $\mathrm{mm}$ ) and temperature $\left(\mathrm{T}\right.$ in $\left.{ }^{\circ} \mathrm{C}\right)$, a given month is consider as dry when $\mathrm{P}<2 \mathrm{~T}$ i.e. when potential evapotranspiration (PET) is greater than the rainfall [42]. Conversely, a month is assumed to be wet when $\mathrm{P}>2 \mathrm{~T}$ [42].

Beyond this seasonal distribution, the yearly seasonal drought is also an important parameter which should be considered in the biomass burning impact on air quality. The amount of biomass burning is dependent on the type of vegetation but also on meteorological factors such intense drought [43]. Therefore, for the purposes of considering this important factor, for each season, De Martonne [44] dryness index has been calculated based on:

$$
I=\frac{12 p(\mathrm{~mm})}{t\left({ }^{\circ} \mathrm{C}\right)+10}
$$

where $t$ is the monthly mean temperature $\left({ }^{\circ} \mathrm{C}\right)$ and $p$ is monthly mean rainfall $(\mathrm{mm})$.

Table 2 presents the mean indexes calculated for each season during the study period. Dryness increases when the index value decreases, a weak dryness associated to more rainfall and/or low temperature.

\subsubsection{Samples Collection and Chemical Analysis}

Since 1994, the chemical signature of the Lamto savannah has been monitored through rainfall, gas and aerosols samples collection. A total of 860 samples were collected and analysed during the study period. The main dissolved chemical substances $\left(\mathrm{H}^{+}, \mathrm{NH}_{4}^{+}, \mathrm{Ca}^{2+}, \mathrm{Mg}^{2+}, \mathrm{Na}^{+}, \mathrm{Cl}^{-}, \mathrm{SO}_{4}^{2-}, \mathrm{NO}_{3}^{-}, \mathrm{C}_{2} \mathrm{O}_{4}^{2-}, \mathrm{HCOOH}\right.$ and $\left.\mathrm{CH}_{3} \mathrm{COOH}\right)$ in the rainwater collected over the study area were determined by using the high performance liquid chromatography technique . Nitrate and oxalate ions were analyzed by ionic chromatography. A full description of the determinations of these chemical species was done by previous studies [38] [41] [45]-[48] and is available at: http://idaf.sedoo.fr.

\subsubsection{Determination of the Partial Pressures in Air}

During cloud formation, the partial pressure of organic monoacid ( $\mathrm{HCOOH}$ or $\left.\mathrm{CH}_{3} \mathrm{COOH}\right)$ in the air is balanced 
Table 1. Seasonal distribution of rainfall in Lamto during 1994-2004.

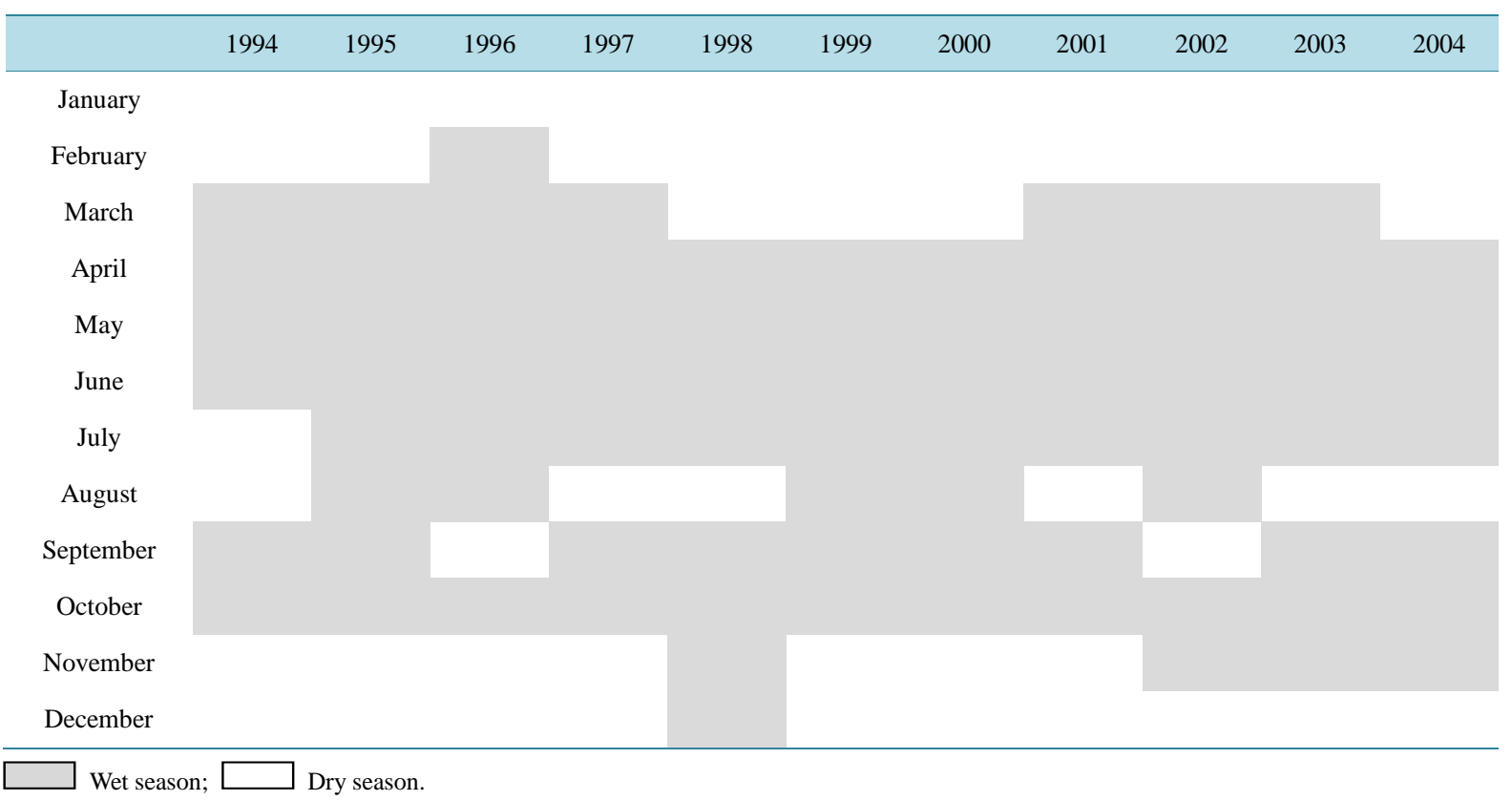

Table 2. Mean dryness for dry and wet seasons during 1994-2004.

\begin{tabular}{cccccccccccc}
\hline Years & 1994 & 1995 & 1996 & 1997 & 1998 & 1999 & 2000 & 2001 & 2002 & 2003 & 2004 \\
\hline Dry season & 0.38 & 0.12 & 0.20 & 0.34 & 0.20 & 0.43 & 0.45 & 0.33 & 0.38 & 0.40 & 0.45 \\
Wet season & 1.43 & 1.73 & 1.67 & 1.56 & 1.23 & 1.72 & 1.57 & 1.55 & 1.46 & 1.76 & 1.22 \\
\hline
\end{tabular}

with the acid concentration on gaseous form present in the rainfall. The gas solubility balance in the aqueous phase of cloud droplet is governs by Henry law [1] [20] [35]. This law is given by:

$$
P_{i}=C_{S} / H
$$

where $P_{i}$ is the gas partial pressure (atm), $C_{S}$ is maximum concentration at saturation (mole/L) and $H$ is the Henry's law constant (mole/Latm).

Considering the acid (AH):

$$
\mathrm{AH}+\mathrm{H}_{2} \mathrm{O} \rightleftarrows \mathrm{H}_{3} \mathrm{O}^{+}+\mathrm{A}^{-}
$$

The partial pressure $P_{g a s}$ of the each carboxylic monoacid in equilibrium with the water cotent of cloud is calculated by:

$$
P_{g a z}=\frac{X}{H\left(1+10^{p H-p K_{a}}\right)}
$$

where $P_{\text {gas }}$ is Gas partial pressure in the air (atm), $X$ is the total concentration of the acid measured in the rainfall water (mole/L), $H$ is the Henry's law constant (mole/L.atm), $\mathrm{pH}$ is the acidity of the rainfall sample and pKa is the $\mathrm{pH}$ at which half of the acid is dissociated.

\section{Results and Discussions}

\subsection{Interannual Evolution of Partial Pressures of Formic and Acetic Acids}

Over the decade (1995-2004), the annual mean partial pressures of organic monoacid (formic and acetic) have been determined. $P_{\text {gas }}$ values vary from 0.003 (1998) ppbv to $0.21 \mathrm{ppbv}$ (1996) for formic acid and from 0.27 (1999) ppbv to 0.45 ppbv (1996) for acetic acid. Figure 2 shows $P_{\text {gas }}$ evolution for the two acids which have 


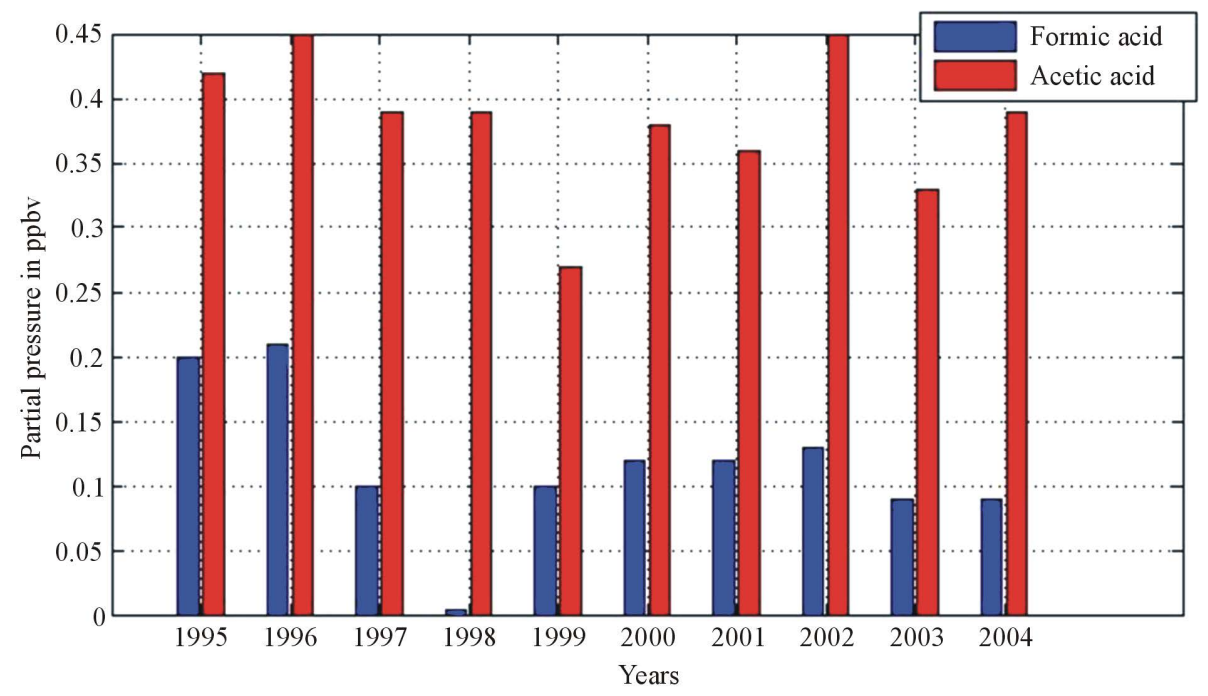

Figure 2. Interannual variability of partial pressures for formic and acetic acid in the air of humid savannah in Lamto.

similar interannual variations. However, the acetic acid appears to be less than the formic over the decade. The mean partial pressure in the air is of $0.12 \pm 0.06 \mathrm{ppbv}$ for a variation coefficient of $50 \%$ against $0.38 \pm 0.06 \mathrm{ppbv}$ with a variation coefficient of $16 \%$ for acetic acid. The decadal mean value of $P_{\text {gas }}$ for the acetic acid is 3.2 times greater than the formic acid. The interannual variability over the decade is related to organic acid sources. The organic acid in the air is dependent on biomass burning, isoprene gaseous phase photochemical, aldehydes oxidation in liquid phase and the direct emission of acid by vegetation [6] [7] [10] [16] [19] [20] [49].

$P_{\text {gas }}$ observed in the atmosphere of the humid savannah Lamto is within the range of values generally observed in the atmosphere of rural areas (Table 3). However, very low values of the order of pptv are obtained Lamto. This can be attributed either to the low contribution of the sources of these acids during that period, to a larger leaching Lamto atmosphere compared to other site. Finally, another explanation could be due to the process of neutralization of acids by Sahara dust brought by the Harmattan. Since it has been shown that this air mass influences the chemical composition of the atmosphere Lamto [38] [40].

\subsection{Seasonal Evolution of Partial Pressures of Formic and Acetic Acids}

$P_{\text {gas }}$ seasonal values for the formic and acetic acid vary from 0.002 (1998) to $0.61 \mathrm{ppbv}$ (1995) and 0.28 (1999) to $0.98 \mathrm{ppbv}$ (1995) respectively during dry season. During wet season, these values vary between 0.003 (1998) and 0.17 ppbv (1996) for formic acid and 0.23 (1999) and 0.44 ppbv (2002) for acetic. Dry season $P_{\text {gas }}$ values are higher than those of the wet season despite the considered acid and year. However, in 1998, the formic acid partial pressure values during the wet season were close to those of the dry season (Figure 3(a)). This pattern is also observed for the acetic acid which partial pressure values are slightly greater than those of dry season (Figure 3(b)). It would find its explanation in our distribution of seasons. Indeed, generally in the distribution of seasons the last two months of the year (November and December) are dry months. However, in 1998 these months are wet overcharged with aridity index of 1.2. In addition, N'datchoh et al. [54] showed that these months are part of the period of intense fires in the West African regions near the Gulf of Guinea and Lamto is located $160 \mathrm{~km}$ from Abidjan big city coastal.

Excluding the 1998, which is a particular year, the mean ration of $P_{\text {gas }}$ for the organic acid during dry season over wet season was $2.5 \pm 0.9 \mathrm{ppbv}$ and $1.8 \pm 0.6 \mathrm{ppbv}$ respectively. The partial pressure of organic acid in the atmosphere of humid savannahs of Lamto increased from factor 2 from wet season to dry season. This seasonal gain is not only explained by rainfall difference between dry and wet season since there is no linearity factors between the dilution factor ( $24.4 \pm 4.82)$ and $P_{\text {gas }}$ variation of organic acid. Therefore, the seasonal variation of organic acid involves several sources with a predominance related to climatologically and meteorological conditions. However, an intensification of organic acids during dry season or additional contribution related to fires may be considered. Biomass burning fires intensification and the additional contribution of fires located far 
Table 3. Levels of formic acid and acetic acid at different sites around the world (ppbv).

\begin{tabular}{cccc}
\hline Location & Formic acid & Acetic Acid & References \\
\hline Equatorial forest of Mayombe (Congo) & 0.08 & 0.13 & Servant et al. [20] \\
Amazonia & 0.20 & 0.20 & Talbot et al. [25] \\
Germany & 0.20 & 0.70 & Hartmann et al. [50] \\
Venezuela & 0.80 & 0.50 & Sanhueza et al. [51] \\
Hawaii & 0.50 & 0.40 & Norton [52] \\
Congo & 0.50 & 0.60 & Helas et al. [53] \\
Humid savannah of Lamto (Côte d'Ivoire) & 0.12 & 0.38 & Present study \\
\hline
\end{tabular}
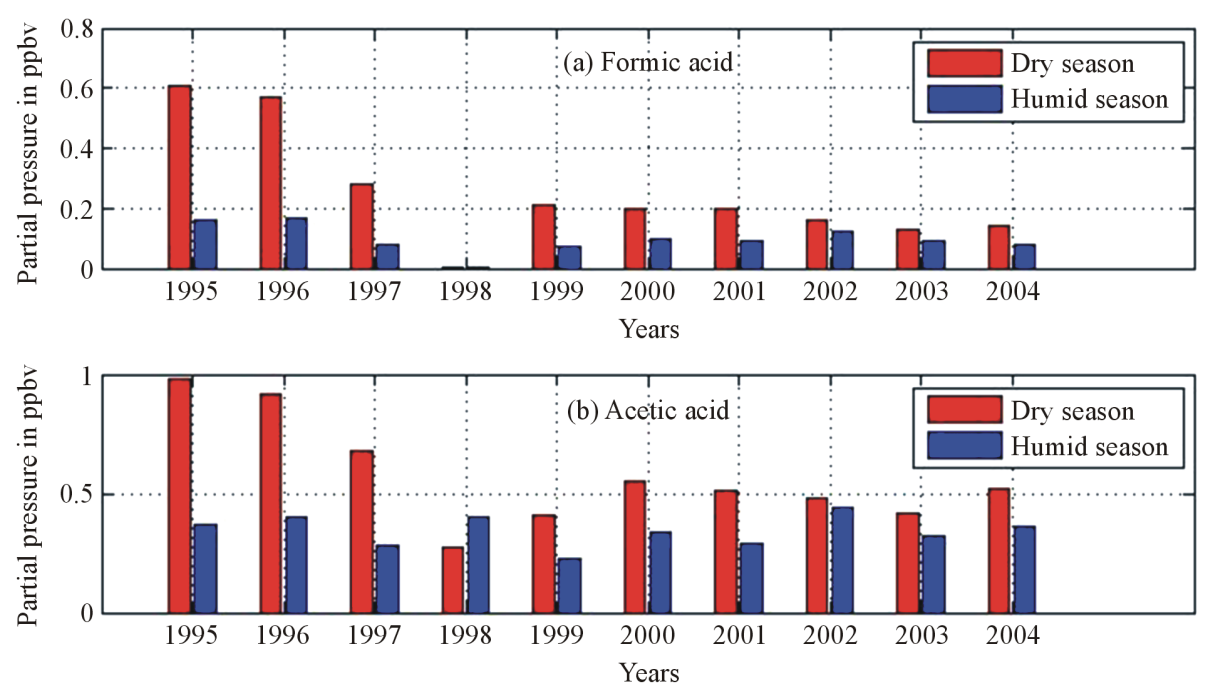

Figure 3. Seasonal partial pressures of organic acids in ppbv over humid savannah of Lamto (a) formic acid; acetic acid during 1995-2004.

away may explain this organic acid concentration increasing during dry season. Indeed, during this period, from October of the previous year to March of the following year, biomass fires are prevalent in West Africa [41] [54] [55].

The decade was not homogeneous. It is interesting to notice that maximum ratios are 3.8 and 2.7 for formic and acetic acids respectively, in 1995, while the minimum values of 1.3 and 1.1 were recorded in 2002 . The low ratio obtained in 2002 could find an explanation in reducing the contributions of local fires. Indeed, from September to December 2002, the migration of the central and northern populations to the cities of the south because of the war has allowed a reduction of agriculture (slash and burn agriculture, hunting, charcoal production) and the resulting forced fallow.

\subsection{Contribution of Organic Acids to Total Free Acidity (TFA) of Rainfall}

In this part of work, to determine the contribution of organic acids to total free acidity (TFA), it is important to introduce oxalic acid in the calculations and the analysis. Because it is the third abundant carboxylic acids measured at Lamto [38].

So to determine organic acidity contribution to the rainfall acidity, the total acidity (TFA) was defined as:

$$
\begin{aligned}
\mathrm{TFA} & =2 \mathrm{nssSO}_{4}^{2-}+\left[\mathrm{NO}_{3}^{-}\right]+\left[\mathrm{A}^{-}\right] \\
\mathrm{nsSSO}_{4}^{2-} & =\left[\mathrm{SO}_{4}^{2-}\right]+\left[\mathrm{SO}_{4}^{2-}\right] \text { maritime }
\end{aligned}
$$


where $\left[\mathrm{nsSSO}_{4}^{2-}\right]$ is the non-maritime sulfate ions concentration, $\left[\mathrm{SO}_{4}^{2-}\right]_{\text {maritime }}$ is the maritime sulfate ions concentration, $\left[\mathrm{SO}_{4}^{2-}\right]$ is the rainfall sulfate ion concentration, $\left[\mathrm{A}^{-}\right]$is the total concentration of organic acids contains in rainfall and $\left[\mathrm{NO}_{3}^{-}\right]$is the Nitrate ions concentration contains in the rainfall.

The most common method used to evaluate the contribution of maritime salt to ions concentration in precipitation is the comparison of the $\mathrm{Cl}^{-}$to $\mathrm{Na}^{+}$ratio measured in the rainfall and the sea waters. It is 1.14 close to the value found by Yoboué et al. [38]. Over Lamto, this ratio is almost equal to that of the sea water (1.16) and was determined as:

$$
[\mathrm{X}]_{\text {maritime }}=[\mathrm{Na}]_{\text {rainfall }} \times[\mathrm{X} / \mathrm{Na}]_{\text {maritime }}[38][56][57]
$$

The concentration of sulfate ions from maritime source was determined at Lamto. This lead to total acidity calculation.

The total acidity values (TFA) over 1998-2004 were determined. The TFA varied between $24.84 \mu \mathrm{eq} \cdot \mathrm{L}^{-1}$ in 1999 and $40.28 \mu \mathrm{eq} \cdot \mathrm{L}^{-1}$ in 2004 during wet season and between $42.47 \mu \mathrm{eq} \cdot \mathrm{L}^{-1}$ in 1998 and $91.78 \mu \mathrm{eq} \cdot \mathrm{L}^{-1}$ in 2004 during dry season. TFA mean values over the study period are $35.02 \pm 5.16$ and $67.32 \pm 23.25 \mu \mathrm{eq} \cdot \mathrm{L}^{-1}$ respectively for wet and dry seasons. TFA variation was weak during wet season but strong during dry season, where they are two times more than the wet season ones. This may be explained by the weighted concentrations during dry season which are higher than the wet season one. The mean contribution of organic acids (Table 4) is $48.9 \%$ for the wet season (27.6\% for formic acid; $13.9 \%$ for acetic acid and $7.4 \%$ for oxalic acid) and $45 \%$ during dry season (27.1\% for formic acid; $9.9 \%$ for acetic acid and $8.4 \%$ for oxalic acid). The contribution to acidity of organic acids (formic, acetic and oxalate) was stable from one season to another. This is similar for the mineral acidity which value is in the same range (40\% to 60\%) generally observed in Equatorial Africa [35] [36] [38] [58]. The organic acidity is in average equivalent to mineral acidity and is one of characteristic of rainfall waters in this region [58].

Comparing to studies of the tropical regions of America and Africa such as Brazil (Amazonia), Congo (Dimonika), Cameroon (Zoétélé) and in less polluted regions of North America and Australia [35] [36] [58]-[62], the contribution of organic acid to total acidity found in Lamto is in the same range as those of the above sites. As for these above cited sites, Lamto is less influenced by anthrogenic activities such as industries and stock farming. Thus the atmospheric acidity is dominated by the organic component which represents $50 \%$ to $80 \%$ of the total acidity.

\subsection{Impact of Biomass Fires}

In the purpose to analyse biomass fires impact, their acid formic and acetic concentration, nitrate ion have been used as chemical tracer. This choice is justified by the existence of strong correlation of this ion and organic acids of rainfall over Lamto and is considered as the best indicator of biomass fires impact on rainfall chemical composition [38] [41]. Biomass fires contribution in the organic acids is made by choosing as reference four fires plumes obtained during Atmospheric Boundary Layer Experiment (ABLE 2A) campaigns conducted in Amazonia in 1988 [35] [58]. The nitrate, formate and acetate ions content measured are summarised in Table 5 together with those measured in Lamto for comparison purpose. For each year, the reference ratio of $[\mathrm{X}]$ to $[\mathrm{Ni}$ trate] was determined which represents biomass fires contribution in organic acids production (formic and acetic) during the dry and wet seasons in Lamto atmosphere (Table 6). Fires contribution to organic acids is variable from year to year. It is higher for a factor of 1.5 during wet season for acetic acid and around factor 2 in dry season. This contribution represent between $13 \%$ and $38 \%$ for formic acid and between $22 \%$ and $48 \%$ for acetic acid. In dry season, this contribution is between $17 \%$ and $38 \%$ for formic acid and $23 \%$ to $80 \%$ for acetic acid. Thus biomass fires are involved about $19 \%$ - 31\% in the production of organic acids production during wet season and $26 \%-51 \%$ during dry season for formic and acetic acids. Biomass fires non negligible contribution to organic monoacids during the wet season may be explained firstly by domestic fires since the African continent energy balance is dominated by biomass usage which represents $2 / 3$ of the total energy consuming [63] [64]. In Côte d'Ivoire, firewood, charcoal, and agricultural waste remains the main source of energy. This represents $73 \%$ of house consummation and more than $95 \%$ of the Ivorian rural population use firewood or charcoal as fuel [65]-[67]. Secondly, it may come from the global pollution while general circulation insures the mixing of several air masses over the continent [41] [68] [69]. Thus during wet season in West Africa, the southern hemisphere as well as the central part of Africa are in dry season where a biomass fire occurs. Therefore, when the 
Table 4. Contribution of acidity of main organic acids measured in rainfall waters in atmosphere of wet savannah of Lamto and determination of TFA during wet and dry seasons over the study period (1998-2004).

\begin{tabular}{|c|c|c|c|c|c|c|c|c|}
\hline \multirow{2}{*}{ Years } & \multicolumn{4}{|c|}{ Wet season } & \multicolumn{4}{|c|}{ Dry season } \\
\hline & $\% \mathrm{OA}^{\mathrm{a}}$ & $\% \mathrm{FA}^{\mathrm{b}}$ & $\% \mathrm{AA}^{\mathrm{c}}$ & $\% \mathrm{AOX}^{\mathrm{d}}$ & $\% \mathrm{AO}^{\mathrm{a}}$ & $\% \mathrm{FA}^{\mathrm{b}}$ & $\% \mathrm{AA}^{\mathrm{c}}$ & $\% \mathrm{AOX}^{\mathrm{d}}$ \\
\hline 1998 & 46.29 & 23.78 & 14.13 & 8.37 & 33.04 & 12.23 & 1.48 & 19.32 \\
\hline 1999 & 37.72 & 20.80 & 12.40 & 4.52 & 36.07 & 25.91 & 5.88 & 4.28 \\
\hline 2000 & 45.86 & 26.07 & 12.91 & 6.89 & 51.24 & 32.62 & 12.35 & 6.26 \\
\hline 2001 & 57.18 & 33.24 & 14.51 & 9.43 & 44.36 & 27.63 & 8.48 & 8.25 \\
\hline 2002 & 57.48 & 34.40 & 15.93 & 7.15 & 53.51 & 32.31 & 14.80 & 6.40 \\
\hline 2003 & 51.11 & 29.82 & 12.45 & 8.84 & 45.26 & 26.84 & 11.20 & 7.23 \\
\hline 2004 & 47.27 & 25.43 & 15.03 & 6.81 & 54.26 & 31.97 & 15.41 & 6.89 \\
\hline Mean & 48.99 & 27.65 & 13.91 & 7.43 & 45.36 & 27.07 & 9.94 & 8.38 \\
\hline Standard deviation & 6.96 & 5.02 & 1.36 & 1.64 & 8.36 & 7.12 & 5.02 & 4.98 \\
\hline
\end{tabular}

${ }^{\mathrm{a}}$ Organic acids; ${ }^{\mathrm{b}}$ Formic acid; ${ }^{\mathrm{c}}$ Acetic acid; ${ }^{\mathrm{d}}$ Oxalic acid.

Table 5. Mean organic anions (fomate, acetate) and nitrate fires plumes over Amazonia forest during ABLE 2A (1998) compared with those in rainfall water during 1995-2004 in Lamto station.

\begin{tabular}{|c|c|c|c|c|c|c|}
\hline \multirow{2}{*}{ Ions } & \multirow{2}{*}{$\begin{array}{c}\text { Amazonia (pulme) } \\
{[\mathrm{X}], \mathrm{ppt}}\end{array}$} & \multicolumn{2}{|c|}{$\begin{array}{l}\text { Lamto (rainfall) } \\
\text { [X], } \mu \text { éq/L }\end{array}$} & \multirow{2}{*}{$\begin{array}{c}\text { Amazonia (plume) } \\
{[\mathrm{X}] /[\text { Nitrate }]}\end{array}$} & \multicolumn{2}{|c|}{$\begin{array}{c}\text { Lamto (rainfall) } \\
{[\mathrm{X}] /[\text { Nitrate] }}\end{array}$} \\
\hline & & Dry & Wet & & Dry & Wet \\
\hline Formate & 2.80 & 23.50 & 13.40 & 0.23 & 0.91 & 1.24 \\
\hline Acetate & 2.00 & 8.50 & 5.70 & 0.16 & 0.33 & 0.53 \\
\hline Nitrate & 302.00 & 25.80 & 10.80 & 1.00 & 1.00 & 1.00 \\
\hline Oxalate & 97.00 & 2.80 & 1.70 & 0.32 & 0.11 & 0.16 \\
\hline
\end{tabular}

Table 6. Biomass fires contribution estimates in organic acid production during wet end dry seasons from 1995 to 2004.

\begin{tabular}{ccccc}
\hline \multirow{2}{*}{ Years } & \multicolumn{2}{c}{ Wet season } & \multicolumn{2}{c}{ Dry season } \\
\cline { 2 - 3 } 1995 & Formate [\%] & Acetate [\%] & Formate [\%] & Acetate [\%] \\
1996 & 16.43 & 40.00 & 28.75 & 80.00 \\
1997 & 17.69 & 40.00 & 28.75 & 80.00 \\
1998 & 16.43 & 26.67 & 28.75 & 76.67 \\
1999 & 23.00 & 40.00 & 25.56 & 76.67 \\
2000 & 28.75 & 32.00 & 38.33 & 80.00 \\
2001 & 20.90 & 32.00 & 17.69 & 32.00 \\
2002 & 13.52 & 22.86 & 28.75 & 76.67 \\
2003 & 15.33 & 22.86 & 19.17 & 32.00 \\
2004 & 38.33 & 26.67 & 28.75 & 76.67 \\
$1995-2004$ & 32.86 & 26.67 & 17.69 & 22.86 \\
\hline
\end{tabular}


West African monsoon is well established over the continent, south-western may transport plumes from southern hemisphere and central part of Africa towards West Africa [41] [43] [70]-[72]. Thus this may considerably impact on Lamto atmospheric chemistry since this region is close to Guinea Golf (approximately $160 \mathrm{~km}$ ) and $41 \%$ of ozone profile obtained by Guinean troposphere radiosonde exploration during wet showed an intrusion of biomass fires plumes coming from southern hemisphere between 800 and $600 \mathrm{hPa}$ [43].

Fires contribution to increase in organic acidity during the dry season compare to the wet season is about $7 \%$ and $18 \%$ for formic and acetic acid respectively. This increment may be attributed to rainfall deficit at this period of the year, which is important and leads to very weak drought indexes ( 0.12 to 0.45$)$. Thus, vegetation particularly grass wither due to dryness in savannah region is favourable to biomass fires.

Dry and wet season's frequency, as well as the drought of the dry season and its length has important impact on biomass fires and organic acidity since its play an important role in biomass availability. Thus, assuming that each year with a long drought and preceded by a relative wet year, meaning with wetter days than the current year, the risk of having more and intense fire is higher than another year in the same conditions but with longer sweet dry season. As illustration, the beginning of dry season and biomass fires contribution in 1999. Generally, in Lamto, the big dry season start in November/December and end in March/April of the following year. However, in 1999, November and December 1998 were particularly wet with 1.2 as drought index, favouring vegetation growth, in opposition to January-February-March 1999 where the drought index is close to 0 (severe drought), associated more contribution of biomass fires to formic (from $23 \%$ to $26 \%$ ) and acetic (from $40 \%$ to $80 \%)$ acids.

Finally, the presents results are similar to those obtained in Dominka forest in northern Congo [62] though the chemical tracer used there was oxalate. Fire contribution was assessed for formate and acetate ions to be $18 \%$ $38 \%$ during wet season and $28 \%$ - 39\% during dry season. Over the African tropical region as well as in forest or savannah regions, atmospheric chemistry is strongly influenced by biomass fires throughout the seasons.

\section{Conclusion}

The present study results show that formic and acetic acids in the atmosphere of Lamto from January 1995 to December 2004 confirmed the important role of two acids in the acid rainfall with a contribution estimated between $45 \%$ and $50 \%$ of the total acidity. Moreover, it is important to underline that biomass fires contribute from $18.9 \%$ to $30.3 \%$ to acid emission for formic and acetic acids respectively during wet season. During the dry season, it is estimated to be $25.3 \%$ for formic acid and $48.6 \%$ for acetic acid emission contribution from biomass fires. This aspect therefore puts a significant emphasis on the role of biomass burning in the atmospheric chemistry of African tropical regions. Ultimately, it would be interesting to carry out in situ measurements of organic acids and volatile organic compounds such as terpenes, isoprene and aldehydes in order of better understanding of the contributions of others sources such as vegetation and photochemical reactions.

\section{References}

[1] Johnson, B.J., Belterton, E.A. and Craig, D. (1996) Henry’s Law Coefficients of Formic and Acetic Acids. Journal of Atmospheric Chemistry, 24, 113-119. http://dx.doi.org/10.1007/BF00162406

[2] Dawson, G.A., Farmer, J.C. and Moyers, J.L. (1980) Formic and Acetic Acids in the Atmosphere of the Southwest U.S.A. Geophysical Research Letters, 7, 725-728. http://dx.doi.org/10.1029/GL007i009p00725

[3] Keene, W.C. and Galloway, J.N. (1988) The Biogeochemical Cycling of Formic and Acetic Acids through the Troposphere: An Overview of Current Understanding. Tellus, 40B, 322-334. http://dx.doi.org/10.1111/j.1600-0889.1988.tb00106.x

[4] Sanhueza, E. and Andreae, M.O. (1991) Emission of Formic and Acetic Acids from Tropical Savanna Soils. Geophysical Research Letters, 18, 1707-1710. http://dx.doi.org/10.1029/91GL01565

[5] Kuhn, U., Rottenberger, S., Biesenthal, T., Ammann, C., Wolf, A., Schebeske, G., Oliva, S.T., Tavares, T.M. and Kesselmeier, J. (2002) Exchange of Short-Chain Monocarboxylic Acids by Vegetation at a Remote Tropical Forest Site in Amazonia. Journal of Geophysical Research, 107, LBA 36-1-LBA 36-18. http://dx.doi.org/10.1029/2000JD000303

[6] Jardine, K., Yañez Serrano, A., Arneth, A., Abrell, L., Jardine, A., Artaxo, P., Alves, E., Kesselmeier, J., Taylor, T., Saleska, S. and Huxman, T. (2011) Ecosystem-Scale Compensation Points of Formic and Acetic Acid in the Central Amazon. Biogeosciences, 8, 3709-3720. www.biogeosciences.net/8/3709/2011/

[7] Khare, P., Kumar, N., Kumari, K.M. and Srivastava, S.S. (1999) Atmospheric Formic and Acetic Acids: An Overview. Reviews of Geophysics, 37, 227-248. http://dx.doi.org/10.1029/1998RG900005 
[8] Vet, R., Artz, R.S., Carou, S., Shaw, M., Ro, C.-U., Aas, W., Baker, A., Bowersox, V.C., Dentener, F., Galy-Lacaux, C., Hou, A., Pienaar, J.J., Gillett, R., Forti, M.C., Gromov, S., Hara, H., Khodzher, T., Mahowald, N.M., Nickovic, S., Rao, P.S.P. and Reid, N.W. (2014) A Global Assessment of Precipitation Chemistry and Deposition of Sulfur, Nitrogen, Sea Salt, Base Cations, Organic Acids, Acidity and pH, and Phosphorus. Atmospheric Environment, 93, 3-100. http://dx.doi.org/10.1016/j.atmosenv.2013.10.060

[9] Yuan, B., Veres, P.R., Warneke, C., Roberts, J.M., Gilman, J.B., Koss, A., Edwards, P.M., Graus, M., Kuster, W.C., Li, S.-M., Wild, R.J., Brown, S.S., Dubé, W.P., Lerner, B.M., Williams, E.J., Johnson, J.E., Quinn, P.K., Bates, T.S., Lefer, B., Hayes, P.L., Jimenez, J.L., Weber, R.J., Zamora, R., Ervens, B., Millet, D.B., Rappenglück, B. and De Gouw, J.A. (2015) Investigation of Secondary Formation of Formic Acid: Urban Environment vs. Oil and Gas Producing Region Atmospheric Chemistry and Physics, 15, 1975-1993. http://dx.doi.org/10.5194/acp-15-1975-2015

[10] Guo, H., Zhou, J., Wang, L., Zhou, Y., Yuan, J. and Zhao, R. (2015) Seasonal Variations and Sources of Carboxylic Acids in PM2.5 in Wuhan, China. Aerosol and Air Quality Research, 15, 517-528. http://dx.doi.org/10.4209/aaqr.2014.02.0040

[11] Talbot, A.W., Beecher, K.M., Charris, R. and Cofer, W.R. (1988) Atmospheric Geochemistry of Formic and Acetic Acids at a Mid-Latitude Temperature Site. Journal of Geophysical Research: Atmospheres, 93, 1638-1652. http://dx.doi.org/10.1029/JD093iD02p01638

[12] Kawamura, K., Ng, L.L. and Kaplan, I.R. (1985) Determination of Organic Acids (C1-C10) in the Atmosphere, Motor Exhausts, and Engine Oils. Environmental Science \& Technology, 19, 1082-1086. http://dx.doi.org/10.1021/es00141a010

[13] Millet, M., Wortham, H., Sanusi, A. and Mirabel, P. (1995) Analysis of Fog in Urban Area: II. Organic Acids and Trace Metals. Pollution Atmosphérique, No. 147, 31-36. http://lodel.irevues.inist.fr/pollution-atmospherique/index.php?id=4006

[14] Helas, G. and Kesselmeier, J. (1993) Estimates on Sinks and Sources of Formic and Acetic Acid. In: Slanina, J., Angeletti, G. and Beilke, S., Eds., General Assessment of Biogenic Emissions and Deposition of Nitrogen Compounds, Sulphur Compounds and Oxidants in Europe, CEC Air Pollution Research Report 47, E. Guyot SA, Brussels, 299-304.

[15] Chebbi, A. and Carlier, P. (1996) Carboxylic Acids in the Troposphere, Occurrence, Sources, and Sinks: A Review. Atmospheric Environment, 30, 4233-4249.

[16] Paulot, F., Wunch, D., Crounse, J.D., Toon, G.C., Millet, D.B., DeCarlo, P.F., Vigouroux, C., Deutscher, N.M., Gonzàlez Abad, G., Notholt, J., Warneke, T., Hannigan, J.W., Warneke, C., de Gouw, J.A., Dunlea, E.J., De Mazière, M., Griffith, D.W.T., Bernath, P., Jimenez, J.L. and Wennberg, P.O. (2011) Importance of Secondary Sources in the Atmospheric Budgets of Formic and Acetic Acids. Atmospheric Chemistry and Physics, 11, 1989-2013.

[17] .Fisseha, R., Saurer, M., Jaggi, M., Siegwolf, R.T.W., Dommen, J., Szidat, S., Samburova, V. and Baltensperger, U. (2009) Determination of Primary and Secondary Sources of Organic Acids and Carbonaceous Aerosols Using Stable Carbon Isotopes. Atmospheric Environment, 43, 431-437. http://dx.doi.org/10.1016/j.atmosenv.2008.08.041

[18] Yokelson, R.J., Christian, T.J., Karl, T.G. and Guenther, A. (2008) The Tropical Forest and Fire Emissions Experiment: Laboratory Fire Measurements and Synthesis of Campaign Data. Atmospheric Chemistry and Physics, 8, 3509-3527. www.atmos-chem-phys.net/8/3509/2008/

[19] .Akagi, S.K., Yokelson, R.J., Wiedinmyer, C., Alvarado, M.J., Reid, J.S., Karl, T., Crounse, J.D. and Wennberg, P.O. (2011) Emission Factors for Open and Domestic Biomass Burning for Use in Atmospheric Models. Atmospheric Chemistry and Physics, 11, 4039-4072.

[20] Servant, J., Kouadio, G., Cros, B. and Delmas, R. (1991) Carboxylic Monoacids in the Air of Mayombe Forest (Congo): Role of the Forest as a Source or Sink. Journal of Atmospheric Chemistry, 12, 367-380. http://dx.doi.org/10.1007/BF00114774

[21] Stavrakou, T., Muller, J.F., Peeters, J., Razavi, A., Clarisse, L., Clerbaux, C., Coheur, P.F., Hurtmans, D., De Maziere, M., Vigouroux, C., Deutscher, N.M., Griffith, D.W.T., Jones, N. and Paton-Walsh, C. (2012) Satellite Evidence for a Large Source of Formic Acid from Boreal and Tropical Forests. Nature Geoscience, 5, 26-30.

[22] Altshuller, A.P. (1991) Estimating Product Yields of Carbon-Containing Products from the Atmospheric Photooxidation of Ambient Air Alkenes. Journal of Atmospheric Chemistry, 13, 131-154. http://dx.doi.org/10.1007/BF00115970

[23] Horie, O., Neeb, P., Limbach, S. and Moortga, G.K. (1994) Formation of Formic Acid and Organic Peroxides in the Ozonolysis of Ethene with Added Water Vapour. Geophysical Research Letters, 21, 1523-1526. http://dx.doi.org/10.1029/94GL01174

[24] Chameides, W.L. and Davis, D.D. (1983) Aqueous Phase Source of Formic Acid in Clouds. Nature, 304, 427-429. http://dx.doi.org/10.1038/304427a0

[25] Talbot, R.W., Andreae, M.O., Berresheim, H., Jacob, D.J. and Beecher, K.M. (1990) Sources and Sinks of Formic, Acetic, and Pyruvic Acids over Central Amazonia. 2. Wet Season. Journal of Geophysical Research: Atmospheres, 95, 16799-16811. http://dx.doi.org/10.1029/JD095iD10p16799 
[26] Graedel, T.E. and Eisner, T. (1988) Atmospheric Formic Acid from Formicine Ants: A Preliminary Assessment. Tellus, 408, 335-339. http://dx.doi.org/10.1111/j.1600-0889.1988.tb00107.x

[27] Ohta, K., Ogawa, H. and Mizuno, T. (2000) Abiological Formation of Formic Acid on Rocks in Nature. Applied Geochemistry, 15, 91-95. http://dx.doi.org/10.1016/s0883-2927(99)00014-1

[28] Keene W.C., et al. (1989) An Intercomparison of Measurement Systems of Vapour and Particulate Phase Concentrations of Formic and Acetic Acids. Journal of Geophysical Research: Atmospheres, 94, 6457-6471. http://dx.doi.org/10.1029/JD094iD05p06457

[29] Talbot, R.W., Andreae, M.O., Berresheim, H., Jacob, D.J. and Beecher, K.M. (1990) Source and Sinks of Formic, Acetic and Pyruvic Acids over Central Amazonia 2. Wet Season. Journal of Geophysical Research: Atmospheres, 95, 799-811. http://dx.doi.org/10.1029/JD095iD10p16799

[30] Talbot, R.W., Dibb, J.E., Scheuer, E.M., Blake, D.R., Blake, N.J., Gregory, G.L., Sachse, G.W., Bradshaw, J.D., Sandholm, S.T. and Singh, H.B (1999) Influence of Biomass Combustion Emissions on the Distribution of Acidic Trace Gases over the Southern Pacific Basin during Austral Springtime. Journal of Geophysical Research: Atmospheres, 104, 5623-5634.

[31] Rinsland, C.P., Mahieu, E., Zander, R., Goldman, A., Wood, S. and Chiou, L. (2004) Free Tropospheric Measurements of Formic Acid (HCOOH) from Infrared Ground-Based Solar Absorption Spectra: Retrieval Approach, Evidence for a Seasonal Cycle, and Comparison with Model Calculations. Journal of Geophysical Research: Atmospheres, 109, D18308. http://dx.doi.org/10.1029/2004jd004917

[32] Yokelson, R.J., Goode, J.G., Ward, D.E., Susott, R.A., Babbitt, R.E., Wade, D.D., Bertschi, I., Griffith, D.W.T. and Hao, W.M. (1999) Emissions of Formaldehyde, Acetic Acid, Methanol, and Other Trace Gases from Biomass Fires in North Carolina Measured by Airborne Fourier Transform Infrared Spectroscopy. Journal of Geophysical Research: Atmospheres, 104, 30109-30125.

[33] Goode, J.G., Yokelson, R.J., Ward, D.E., Sussot, R.A., Babbitt, R.E., Davies, M.A. and Hao, W.M. (2000) Measurements of Excess $\mathrm{O}_{3}, \mathrm{CO}_{2}, \mathrm{CO}, \mathrm{CH}_{4}, \mathrm{C}_{2} \mathrm{H}_{4}, \mathrm{C}_{2} \mathrm{H}_{2}, \mathrm{HCN}, \mathrm{NO}, \mathrm{NH}_{3}, \mathrm{HCOOH}, \mathrm{CH}_{3} \mathrm{COOH}, \mathrm{HCHO}$, and $\mathrm{CH}_{3} \mathrm{OH}$ in 1997 Alaskan Biomass Burning Plumes by Airborne Fourier Transform Infrared Spectroscopy (AFTIR). Journal of Geophysical Research: Atmospheres, 105, 22147-22166.

[34] Herndon, S.C., Zahniser, M.S., Nelson Jr., D.D., Shorter, J., McManus, J.B., Jimenez, R., Warneke, C. and de Gouw, J.A. (2007) Airborne Measurements of HCHO and HCOOH during the New England Air Quality Study 2004 Using a Pulsed Quantum Cascade Laser Spectrometer. Journal of Geophysical Research: Atmospheres, 112, Article ID: D10S03.

[35] Kouadio, K.G. (1991) Study of the Origin of Organic Acids in the Atmosphere of a Rainforest: Case of Mayombe (Congo). PhD Thesis, Paul Sabatier University, Toulouse.

[36] Sigha-Nkamdjou, L., Galy-Lacaux, C., Pont, V., Richard, S., Sighomnou, D. and Lacaux, J.P. (2003) Rainwater Chemistry and Wet Deposition over the Equatorial Forested Ecosystem of Zoétélé (Cameroon). Journal of Atmospheric Chemistry, 46, 173-198.

[37] Mphepya, J.N., Pienaar, J.J., Galy-Lacaux, C., Held, G. and Turner, C.R. (2004) Precipitation Chemistry in Semi-Arid Areas of Southern Africa: A Case Study of a Rural and an Industrial Site. Journal of Atmospheric Chemistry, 47, 1-24. http://dx.doi.org/10.1023/B:JOCH.0000012240.09119.c4

[38] Yoboué, V., Galy-Lacaux, C., Lacaux, J.P. and Silué, S. (2005) Rainwater Chemistry and Wet Deposition over the Wet Savanna Ecosystem of Lamto (Côte d'Ivoire). Journal of Atmospheric Chemistry, 52, 117-141.

[39] Akpo, A.B., Galy-Lacaux, C., Laouali, D., Delon, C., Liousse, C., Adon, M., Gardrat, E., Mariscal, A. and Darakpa, C. (2015) Precipitation Chemistry and Wet Deposition in a Remote Wet Savanna Site in West Africa: Djougou (Benin). Atmospheric Environment, 115, 110-123.

[40] Yoboué, V. (1991) Physical and Chemical Characteristics of Aerosols and Rainwater Collected in the Humid Savannah of Côte d'Ivoire. PhD Thesis, Paul Sabatier University, Toulouse.

[41] Adon, A.M. (2011) Study of the Concentrations of Atmospheric Gases and Estimated Dry Deposition flux Scale of the Main African Ecosystems. PhD Thesis, Paul Sabatier University of Toulouse and F.H. Boigny University of Côte d'Ivoire.

[42] Gaussen, H. and Bagnouls, F. (1953) Dry Season and Xerothermic Index. Bulletin de la Société d'Histoire Naturelle de Toulouse, 88, 193-240.

[43] Saunois, M. (2009) Tropospheric Ozone Balance on the African Continent: Contribution from AMMA Chemistry Program. PhD Thesis, Paul Sabatier University, Toulouse.

[44] De Martonne, E. (1926) Aréisme et indice d’aridité. Comptes Rendus Académie des Sciences, 181, 1395-1398.

[45] Galy-Lacaux, C. and Modi, A.I. (1998) Precipitation Chemistry in the Sahelian Savannah of Niger, Africa. Journal of Atmospheric Chemistry, 30, 319-343. http://dx.doi.org/10.1023/A:1006027730377 
[46] Yoboué, V., Kouadio, K.G., Silué, S. and Daniel, K. (2003) Study of Rainwater Chemistry in the Humid Savannah of Lamto Cote d'Ivoire. Journal de la Société Ouest-Africaine de Chimie, 15, 79-96.

[47] Mphepya, J.N., Galy-Lacaux, C., Lacaux, J.P., Held, G. and Pienaar, J.J. (2006) Precipitation Chemistry and Wet Deposition in Kruger National Park, South Africa. Journal of Atmospheric Chemistry, 53, 169-183.

[48] Galy-Lacaux, C., Laouali, D., Descroix, L., Gobron, N. and Liousse, C. (2008) Long Term Precipitation Chemistry and Wet Deposition in a Remote Dry Savanna Site in Africa (Niger). Atmospheric Chemistry and Physics Discussion, 8, 5761-5812. www.atmos-chem-phys-discuss.net/8/5761/2008/

[49] Bannan, T.J., Bacak, A., Muller, J.B.A., Booth, A.M., Jones, B., Le Breton, M., Leather, K.E., Ghalaieny, M., Xiao, P., Shallcross, D.E. and Percival, C.J. (2014) Importance of Direct Anthropogenic Emissions of Formic Acid Measured by a Chemical Ionisation Mass Spectrometer (CIMS) during the Winter ClearfLo Campaign in London, January 2012. Atmospheric Environment, 83, 301-310.

[50] Hartmann, W.R., Andreae, M.O. and Helas, G. (1989) Measurements of Organic Acids over Central Germany. Atmospheric Environment, 23, 1531-1533. http://dx.doi.org/10.1016/0004-6981(89)90412-5

[51] Sanhueza, E., Santana, M. and Hermoso, M. (1992) Gas- and Aqueous-Phase Formic and Acetic Acids at a Tropical Cloud Forest Site. Atmospheric Environment. Part A. General Topics, 26, 1421-1426. http://dx.doi.org/10.1016/0960-1686(92)90127-7

[52] Norton, R.B. (1992) Measurements of Gas Phase Formic and Acetic Acids at the Mauna Loa, Observatory, Hawaii during the Mauna Loa Observatory Photochemistry Experiment 1988. Journal of Geophysical Research: Atmospheres, 97, 10389-10393. http://dx.doi.org/10.1029/91JD02297

[53] Helas, G., Bingemer, H. and Andreae, M.O. (1992) Organic Acids over Equatorial Africa: Results from DECAFE 88. Journal of Geophysical Research: Atmospheres, 97, 6187-6193. http://dx.doi.org/10.1029/91JD01438

[54] N’Datchoh, E.T., Konaré, A., Diedhiou, A., Diawara, A., Quansah, E. and Assamoi, P. (2015) Effects of Climate Variability on Savannah Fire Regimes in West Africa. Earth System Dynamics, 6, 161-174. www.earth-syst-dynam.net/6/161/2015/

[55] Hélène, D. (2007) The Multiplicity of Scales in the Analysis of a Phenomenon at the Nature/Society Interface. The Example of Bushfires in West Africa. Environment, Nature, Paysage, 363.

[56] Keene, W.C., Pszenny, A.A.P., Galloway, J.N. and Hawley, M.E. (1986) Sea-Salt Corrections and Interpretation of Constituent Ratios in Marine Precipitation. Journal of Geophysical Research: Atmospheres, 91, 6647-6658.

[57] Watanabe, K. and Honoki, H. (2003) Notes and Correspondence on the Kosa (Asian Dust) Event in November 2002: Aerosol Number Concentration and Precipitation Chemistry in Toyama, Japan. Journal of the Meteorological Society of Japan, 81, 1489-1495.

[58] Lacaux, J.P and Sigha, L. (2003) Acid Wet Deposition in the Tropic: Two Case Studies Using DEBITS Measurements IGAC. Activities Newsletter, No. 27, 17-19.

[59] Andreae, M.O., Tabolt, R.W., Andreae, T.W. and Harris, R.C. (1988) Formic and Acetic Acid over the Central Amazon Region Brazil: 1. Dry Season. Journal of Geophysical Research: Atmospheres, 93, 1616-1624.

[60] EPA (1994) Quality Assurance Handbook for Air Pollution Measurement Systems. EPA/600R-94/038e, United States Environment Protection Agency, Office of Research and Development, Washington DC.

[61] Galloway, J.N., Likens, G.E., Keene, W.C. and Miller, J.M. (1982) The Composition of Precipitation in Remote Areas of the World. Journal of Geophysical Research: Oceans, 87, 8771-8786.

[62] Lacaux, J.P., Delmas, R., Kouadio, G., Cross, B. and Adreae, M.O. (1992) Precipitation Chemistry in the Mayombe Forest of Equatorial Africa. Journal of Geophysical Research: Atmospheres, 97, 6195-6206.

[63] Sokona, Y. and Thomas, J.P. (1997) The Energy in Rural Areas in Africa for the Environment and against Poverty: Which Priorities for the Energy Sector in Africa in 2020, Enda.

[64] Mercier, J.R. (1991) Deforestation in Africa: Situation and Outlook, Edisud, Opportunities and Constraints, Energy, Environment and Development in Africa, Vol. 1.

[65] Environment Directorate (2000) Initial National Communication of Côte d’Ivoire. Ministry of Environment, Water and Forestry, Côte d'Ivoire.

[66] Ministère du Logement, du Cadre de vie et de l’Environnement (1997) Côte d’Ivoire: Environmental Profile of Coastal zone. Abidjan Ministry of Housing, and the Environment.

[67] Djezou, W.B. (2009) Analysis of Energy Consumption and Sustainable Management in Côte d’Ivoire. Economics Analysis Unit of CIRES.

[68] Avery Jr., G.B., Kieber, R.J., Witt, M. and Willey, J.D. (2006) Rainwater Monocarboxylic and Dicarboxylic Acid Concentrations in Southeastern North Carolina, USA, as a Function of Air-Mass Back-Trajectory. Atmospheric Environment, 40, 1683-1693. http://dx.doi.org/10.1016/j.atmosenv.2005.10.058 
[69] Fadnavis, S., Semeniuk, K., Schultz, M.G., Kiefer, M., Mahajan, A., Pozzoli, L. and Sonbawane, S. (2015) Transport Pathways of Peroxyacetyl Nitrate in the Upper Troposphere and Lower Stratosphere from Different Monsoon Systems during the Summer Monsoon Season. Atmospheric Chemistry and Physics Discussion, 15, 15087-15135. www.atmos-chem-phys-discuss.net/15/15087/2015/

[70] Kaufman, Y.J., Koren, I., Remer, L.A., Tanré, D., Ginoux, P. and Fan, S. (2005) Dust Transport and Deposition Observed from the Terra-Moderate Resolution Imaging Spectroradiometer (MODIS) Spacecraft over the Atlantic Ocean. Journal of Geophysical Research: Atmospheres, 110, Article ID: D10S12.

[71] Sauvage, B., Gheusi, F., Thouret, V., Cammas, J., Duron, J., Escobar, J., Mari, C., Mascart, P. and Pont, V. (2007) Medium-Range Mid-Tropospheric Transport of Ozone and Precursors over Africa: Two Numerical Case Studies in Dry and Wet Seasons. Atmospheric Chemistry and Physics, 20, 5357-5370.

[72] Mari, C.H., Cailley, G., Corre, L., Saunois, M., Atti, J.L., Thouret, V. and Stohl, A. (2008) Tracing Biomass Burning Plumes from the Southern Hemisphere during the AMMA 2006 Wet Season Experiment. Atmospheric Chemistry and Physics, 8, 3951-3961. www.atmos-chem-phys.net/8/3951/2008/ 